\title{
Trade Liberalization and Tax Revenue Performance in Uganda
}

\author{
Micah Samuel Gaalya \\ Research and Planning Division, Commissioner General's Office, Uganda Revenue Authority, Kampala, Uganda \\ Email: mgaalya@gmail.com
}

Received 22 January 2015; accepted 9 February 2015; published 11 February 2015

Copyright (C) 2015 by author and Scientific Research Publishing Inc.

This work is licensed under the Creative Commons Attribution International License (CC BY). http://creativecommons.org/licenses/by/4.0/

c) (i) Open Access

\begin{abstract}
The study uses fixed and random effects models to establish the determinants of tax revenue performance. The data cover the period 1994 to 2012 , with the results suggesting that exchange rates, trade openness and share of industry to GDP positively influence tax revenue performance while the agriculture share to GDP and foreign aid negatively influence tax revenue performance. Importantly the coefficient for trade openness that is used as a proxy for trade liberalization indicates a positive influence on tax revenue performance.
\end{abstract}

Keywords

Trade Liberalization, Tax Revenue Performance, Tax to GDP Ratio

\section{Introduction}

Trade reforms have been a major economic feature of the world trade system for the latter part of the twentieth century. Trade reforms have seen a substantial expansion in trade flows, capital movements, information and technology as well as mobility of labour across borders. These have led to an increase in world production and consequently an improvement in world economic welfare. During the period, physical distances have become less significant, cultural differences have been reduced, consumption patterns as well as tastes and preferences have begun converging. Accordingly, the world economy has grown closer as trade regimes are modified and trade barriers reduced.

Trade reforms are associated with the reduction, removal and elimination of tariff and other trade barriers such as quotas on imports, subsidies and non-tariff barriers. They also include the removal of trade-distorting policies, free access to market information, reduction of monopoly or oligopoly power, free movement of capital and labour between and within countries and the creation of free trade zones. Trade liberalization can also take other forms of liberalization such as free trade area, trade blocs and free trade agreements e.g. bilateral, multilateral or regional [1]. 
Theoretically the influence of trade liberalization on imports is considered to be an indirect outcome derived from the response of consumption and production decisions to price changes, with price changes triggered by trade reforms [2] [3]. There are two conflicting issues concerning imports in developing countries. First, for balance of payment it may be necessary to restrict imports. Deterioration in balance of payment and terms of trade makes it necessary for developing countries to restrict imports. Second, the restriction of imports does not only cause import revenue and overall revenues to fall but can also lead to an exacerbation of inflationary tendencies in the domestic economy. In some cases, some of the policies designed to restrict imports or increase revenue may have the opposite effect. In fact, Import demand stability is a prerequisite for an effective trade policy [4]. In other words, effective trade policy formulation requires that the change in import demand does not change significantly over time.

Trade liberalization, particularly a reduction of import tariffs, could lead to revenue reduction and create macroeconomic difficulties for some countries. The fear of this revenue reduction, on the part of the policy makers of some countries, could reduce the support for further trade liberalization unless that revenue reduction could be compensated by other revenue. As in most African economies, Uganda implemented Structural Adjustment Programmes (SAPs) in the late 1980's and early 1990's. The programmes and policy measures sought to reduce external disequilibrium while strengthening production capacity. Among the principal measures to bring about external balance, the SAP policies attempted to influence imports demand and tax performance.

In the decades of the 1960's and 1970's fiscal economist interested in developing countries studied the way in which tax systems had developed over long periods and formulated what came to be called the theory of tax structure developments. Inter alia, the theory of tax structure development argued that as countries developed they progressively changed their tax structure to adopt it to the changes in economic structure. More specifically they tend to replace trade taxes with domestically based taxes [5]. This development has characterized many countries including Uganda. For example in the early 1980's, Uganda collected as much as 73 percent of its total revenue from trade taxes. Today it collects almost 39.9 percent.

A study by Tanzi [5] observed that while the replacement of trade taxes with domestic taxes would occur as a natural process accompanying growth, trade liberalization and specific policy decisions. The natural process would accelerate this process by forcing some countries to reform their tax systems more quickly in order to protect the level of their tax revenue. Not all countries would find it easy for the reform of their tax system to replace revenue from trade taxes with other revenue. The structure of the economies, the sophistication of the tax administrations, or political obstacles, could make the needed reforms particularly difficult, or requiring more time in some countries.

Tanzi [5] further notes that in any case it is of fundamental importance for the policy makers of countries that face a process of trade liberalization to address systematically and in an informed way the question of the potential impact of that process on their tax systems. It is important to anticipate that impact and to take the necessary actions in a timely fashion if it is concluded that the impact could be significant. Countries should avoid being faced by unpleasant surprises. By potentially changing the structure of the economy, trade liberalization will affect not just tax revenue but also the role of the state in the economy and thus also public spending. In this study we focus on tax revenue performance.

\section{Problem Statement}

Prior and during the reform period, Uganda became more preoccupied with mobilizing external financial assistance, thereby incurring debt. The debt burden, however, has caused a decrease in public investment spending and an increase in budgetary deficits. Uganda has also undertaken substantial trade liberalization in an effort to improve its balance of payment situation [6]. This necessitated knowledge of the determinants of tax revenue performance. It has also become necessary to determine whether the pattern of tax revenue performance has changed due to these policy changes. There is an explanation related to revenue losses resulting from the trade reforms in the country [7], especially the process of trade liberalization which has involved major reductions in statutory rates of tariffs. Trade liberalization has seen the average tariff rate decline from 25.1 percent in 1985 to 7.1 percent in 2010 (Figure 1). This explanation requires an empirical analysis to understand the determinant tax revenue performance.

An empirical investigation into determinants of low tax revenue performance is important for the following reason: policy makers and other stakeholders need pertinent information to make policy relevant decisions re- 


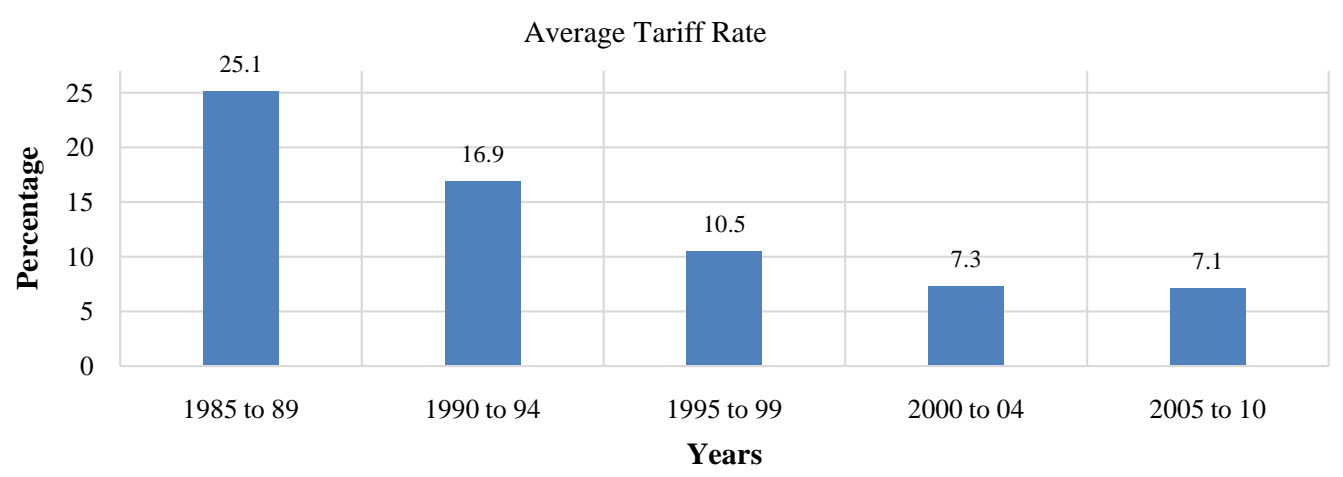

Figure 1. Patterns of Uganda average tariffs. Source: Author's computation based on the World Bank's World Development Indicators (WDI) database, COMTRADE and TRAINS data, July 2013. Note: 5 year averages for the period 1985-2010.

garding trade liberalization for development purposes. This study seeks to contribute to the process of enhancing the capacity of policy makers to choose among the alternative policy options for Uganda's trade preferences.

\section{Tax Policy Environment and Tax Revenue in Uganda}

Uganda's tax revenue performance shows that the initial focus of tax policy in the late 1980's and early 1990's was on reducing the heavy dependence on international trade taxes that had developed in the 1970's. While heavy dependence on international trade taxes is not uncommon in low income countries, Uganda was unusual in its reliance on revenue from export taxes that were inherited during the colonial era. During the 1980's export duty, mainly from coffee exports, contributed as much as 50 percent of total government revenue [7]. This became a major deterrent to export production and an impediment to bring economic growth. The phasing out of export taxes in the early 1990's signaled a deliberate change to the tax system designed to reduce anti-export bias and encourage increased international trade.

The removal of export duties was complemented by a gradual scaling down of import tariffs. In the early 1990's import tariffs were high, making them the largest single contributor to total tax revenue in Uganda. By the end of the decade, the highest import duty rate had been reduced and the import duty regime had been greatly simplified. In addition, import bans and other nontariff barriers were scaled down and various discriminatory taxes on imports were reduced. Equally, as a member, Uganda was party to COMESA's and EAC's programmes to gradually move towards zero tariffs on trade with other member countries [7].

In essence, the tax structure that was extremely distorted and strongly discouraged production for export in the 1980's was gradually replaced by a stable, liberal regime, which is broadly in line with international best practice. This was intended to reduce reliance on international trade taxes and increase domestic taxes. This would be achieved through stimulating domestic production that would generate domestic tax revenue to finance Uganda's development budgets, especially through increasing direct and indirect domestic tax revenues in the medium and long run [7]. Other tax policy measures taken to increase direct and indirect domestic taxes include: introduction of Value Added Tax in 1996, reform of the Income Tax system in 1997, introduction of the Tax Appeals Tribunal (TAT) under the TAT Act in 1997, formation of the Large Taxpayer Department in 1998, Automation of tax administration, among others. These were intended to widen the tax base and make the tax system more equitable for businesses and consumers.

The effects of trade reform on revenue collection show that almost all the tax revenue improvement has been in two areas: indirect domestic taxes and direct domestic taxes. The indirect taxes show that Sales Tax and CTL increased from 1.8 percent of GDP in 1991/92 to 3.4 percent in 1995/96. The introduction of VAT in 1996/97 (VAT replaced Sales Tax and CTL) saw VAT increase from 1.09 percent of GDP to 4.4 percent of GDP in 2012/13 [8]. However, Uganda's average VAT efficiency ratio of 0.21 for the period 1998/99 to 2011/12 is still well below the average of 0.27 for sub-Saharan Africa established by [9].

The direct taxes show that income taxes increased steadily from the exceptionally low level of 0.9 percent to 4.1 percent of GDP between 1991/92 and 2011/12. Most of the increase came from individual income tax, which increased steadily from 0.12 percent to 2.1 percent of GDP between 1991/92 and 2011/12. This was un- 
derlined by improvements in tax administration and tax compliance. The steady growth of the Ugandan economy, particularly in the services and industry, also increased the taxable base. The growth in the service sector, particularly banking and telecommunications, contributed to the accelerated improvement from 2001/02. Other income taxes mainly withholding tax, presumptive tax, tax on bank interest, and rental tax have assumed steadily increasing importance over the period, reaching 2.1 percent of GDP in 2011/12 long run [7].

Despite the increasing tax revenue collections, tax revenue GDP ratio has remained low (Figure 2). For example, the tax revenue GDP ratio has averaged at 13.18 percent compared to the East Africa countries average of about 18.1 percent (Figure 2). If the East African countries average is a calibration to go with, then it suggests that the contributions of tax revenue to GDP in Uganda are not performing well.

Uganda's tax revenue GDP ratio stands today at 13.4 percent and it remained at this level for the last 10 years (Figure 2). The low tax revenue GDP ratio in recent years has come at a time when government's efforts have been progressively focused on trade liberalization, under the stimulus of several IMF programs. Greater emphasis has been placed on budget deficit reduction in order to contain the rate of inflation and restore a measure of fiscal sustainability by arresting the increase in the debt to GDP ratio [6]. But the low tax revenue GDP ratio has made this task increasingly difficult, necessitating sharp cutbacks in public expenditure, especially on development, thereby affecting the growth momentum of the economy. In general the objective of the trade and tax policy reforms was to stimulate Uganda's domestic productivity; however, increased import demand through trade liberalization could affect domestic productivity by crowding out domestic production in favour of imported goods. This in the long run impacts on a country's ability to generate domestic tax revenue to finance its development budgets. Trade liberalization could reduce domestic productions in favour of imported goods and services [8]. With the overall outcome leading to lower direct and indirect domestic tax revenue outturn.

\section{Literature on Trade Liberalization and Tax Revenue Performance}

The impact of the recent trade policy reform on taxation has attracted considerable attention both in the theoretical and empirical literature. Literature suggests that trade policy reform has a variety of outcomes. These include economies of scale, terms of trade effects, changes in relative import prices, dynamic effects resulting from capital inflows, technology transfers and increased competition. In general, the outcome of a given trade policy reform influences performance of the overall economy. This section offers a discussion on the theoretical and empirical literature on determinants of tax revenue.

\subsection{Tax Revenue Performance}

The determinants of tax revenue performance have attracted the attention of many different researchers. In this sense, there is a considerable set of studies examining the trends in tax revenues performance and the relevant factors that influence tax revenue. It is important to refer that most of the aforementioned analysis is focused on developed countries, but some other studies have focused their attention in developing countries. The studies

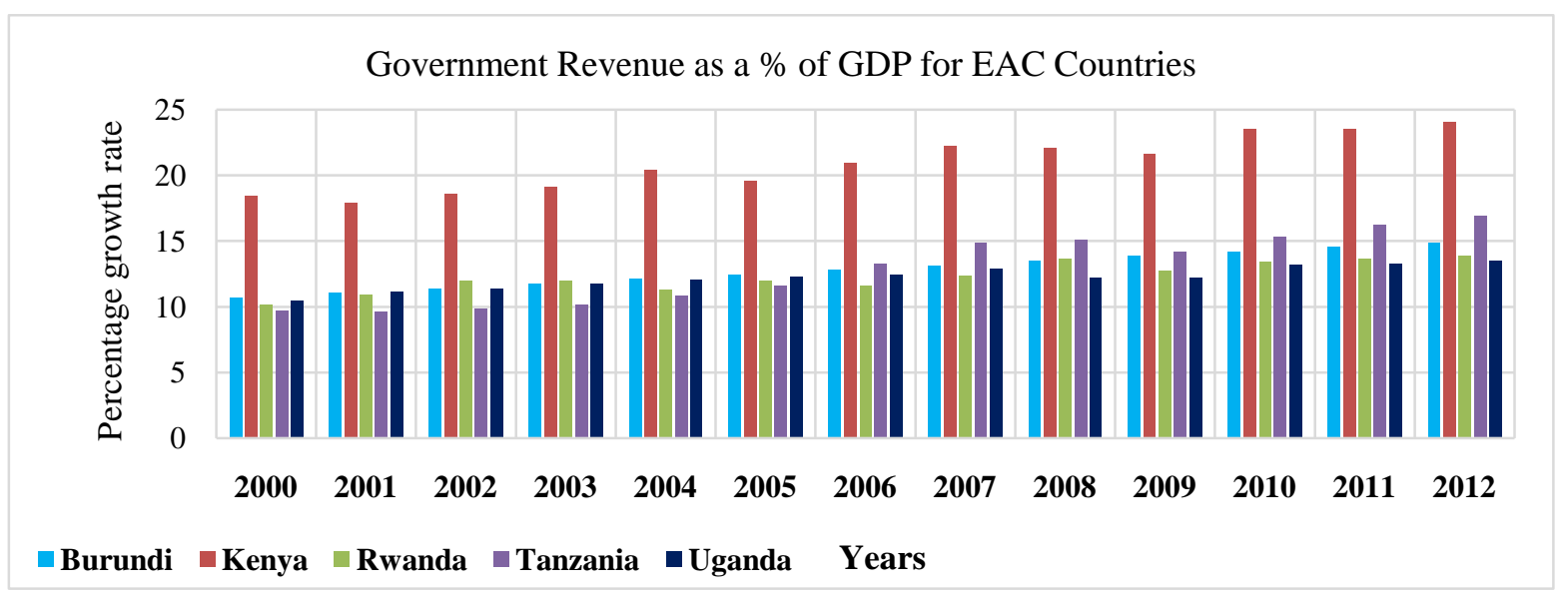

Figure 2. Revenue as a percentage of GDP for EAC countries. Source: Author's computation based on the World Bank's World Development Indicators (WDI) database and MFPED Background to the Budget various years 20002012. 
stress the importance of structural factors, international factors and institutional factors in influencing tax revenue performance in these countries. Some of the studies that have attempted to explore the determinants of tax revenue performance include work by [9]-[14]. Despite these studies are very few, studies have paid attention to issues concerning the consequence of trade reforms on erosion of tax bases. This leads to an argument whether trade liberalization is a potential source of tax revenue volatility, especially for countries which have high dependency on international trade. Trade liberalization in many low income countries is a very sensitive issue because it raises the question of revenue losses. This is a big question for many of low income countries since tax revenues fall short of budget expenditures.

The fear that trade reform could lead to a loss in tax revenue seems to be a big issue in low income countries. The percentage of international trade tax to total tax revenues is estimated at an average of 26 percent in low income countries. This is a relatively high percentage in comparison to high income countries whose ratio stands at an average of about 0.5 percent [15]. Because of such a high share of international trade tax revenue to total revenue, any low income country which commits itself to any form of trade liberalization must be concerned about how to mitigate the probable revenue loss. In response to the problem of revenue losses, some studies suggest that this problem can be solved if trade liberalization is coordinated with government expenditure requirements such as the use of effective tax measures to enhance direct and indirect tax revenues, widening the tax bases, improving efficiencies and effectiveness of government expenditure, raising public saving and strengthening tax administration [16]. However, the above postulations need to be validated in different economic environments to see their effectiveness. Many low income countries attempting to prevent the adverse effects of trade liberalization on trade revenue find it challenging to implement the above postulations. The reason for failure to implement the postulation lies in the structural limitations experienced by low income countries. The limitations relate to constrained institutional capacities, political instability and economic structures favoring trade in agricultural commodities compared to industry and service trade [17].

The more likely solution to this problem would be cutting government expenditure as a response to plummeting international trade taxes. However, this seems not to be practical since it directly reduces social welfare in some of the low income countries. Therefore government expenditures on the social sector such as health, education, and infrastructure and poverty reduction initiatives cannot easily be reduced because they could raise social discontent and uproar in these countries. The other option would be to increase uptake of country programmable aid but most low income countries are stuck with high debt burdens at high concessional and non-concessional repayment rates. Therefore trade liberalization in low income countries has major consequences that require an evaluation to inform the stakeholders on the probable course of action after trade liberalization.

\subsection{Theoretical Literature on Tax Revenue Performance}

Several approaches have been used to establish the determinants of tax revenue performance for different countries. The leading three approaches include: the behavioral approach, stochastic frontier analysis or short run and long run tax revenue functions and the deviations approach which involves looking at the deviations between what a country would like to raise in tax revenues as revealed by the persistent or structural choice of the level of public expenditures and its actual tax collections tax capacity compared to tax collection.

In the first approach, which we term as the traditional regression approach or behavioral approach, tax performance is measured by comparing actual tax collection to the percentage of potential tax revenues. The potential tax revenue is generated from the predicted values based on regression analysis. Some early contributions to this discussion were by [13] [14]. Later on, [15] [18] contributed to literature using this approach. The advantage of this approach lies in its simplicity. Data on the dependent variables are easily available and the estimation models do not impose complex restrictions on the estimation parameters. This approach takes into consideration structural economic features that are likely to affect tax performance. In an international cross country setting, this approach of calculating tax performance serves a useful purpose of providing comparisons on the size of government revenue across countries of different economic structure and tax bases.

The second approach is the stochastic frontier analysis, according to [19] this approach has featured prominently in recent studies of tax performance. It uses the stochastic term and determinants of taxable bases in estimating tax performance. The analysis is conducted into two stages. In the first stage, stochastic frontier analysis is used to model tax performance while in the second stage factors influencing the time-varying inefficiency in tax performance are identified. This approach has the advantage of identifying weak areas of administration and 
institutional environment. These sources of time-varying inefficiency are generally important to tax reform and typically are more amenable to reform measures than structural variables over shorter spans of time.

The estimated tax performance from the traditional regression approach and the stochastic frontier analysis are highly correlated. This suggests that the two methods are quite substitutable. Thus, the advantage of the stochastic frontier approach may simply lie in having a more transparent interpretation of specific institutional constraints to tax performance in a given country. On the other hand, both the traditional regression and stochastic frontier approaches are limited in that they do not generate country specific measures of tax potential that are cogent to national policy.

The third alternative approach to estimating tax performance is through the deviations approach which involves looking at the deviations between what a country would like to raise in tax revenues as revealed by the persistent or structural choice of the level of public expenditures and its actual tax collections. This approach mimics the Ricardian Equivalence by arguing that it should be possible for taxpayers to see the current deficit as future taxes. Therefore, the deficit is a measure of the discrepancy between the desired level of taxation or preferred level of public expenditures and the current level of taxation. This approach has the advantage of assessing tax performance while accommodating preferences for the size of a government in a country.

Under this approach we would use the actual level of public expenditures or some moving average of that variable as an indicator of desired level of taxation in a country, revealed through the political process. This method is closely related to the revenue adequacy approach that considers the overall balance between expenditures and revenues [20]. On the other hand, this approach is still an agenda for tax policy discussions and it yet to be widely used. The methods for the analysis of tax performance have shown that the traditional regression approach, stochastic frontier analysis and deviations approach are used to estimate tax performance. The other methods that determine tax performance can be theoretically explained by these three leading approached. The traditional regression approach is the preferred empirical method for this chapter given its advantages of data requirement.

\subsection{Empirical Literature on Tax Revenue Performance}

There have been a number of empirical studies on the determinants of tax revenue performance. Tax revenue is thought to decline after countries liberalize their international trade tax regime. Economic theory points out that the reduction in imports tariff often leads to a decline in international trade tax revenue especially for small open economies. International trade taxes contribute significantly to total tax revenue in small open countries.

A number of empirical studies have been undertaken to assess tax performance across different countries. Most of the studies have used tax share in GDP as the dependent variable with different combinations of explanatory variables. Martinez-Vazquez and McNab [20] used the data of developed and developing countries to find the ratio of tax revenue to GNP. They used per capita GNP and openness for their study. Their results showed the positive and statistically significant effect for both per capita GNP and for openness.

Another study by Chelliah et al. [21] using data of 47 countries during for period 1969-1971 regressed the tax share in GNP on agriculture share, mining share and export share. The results showed the negative and significant effect on agriculture share, positive and significant effect on mining share and export share.

The study by Stotsky and WoldeMariam [18] examined the tax share for African countries by taking the share of agriculture in income, mining share, per capita income and export ratio as its determinants. Their results showed that agricultural share has negative effect, mining share has positive effect while the share of foreign trade and the share of foreign grants and loans have also positive and statistically significant relation.

A similar study by Bahl [13] by using the data of OECD and less developed economies explained the determinants of tax revenue. He used the non-agricultural share of GDP, openness and the rate of population growth. All variables showed positive and statistically significant result. While the size of shadow economy showed the negative but statistically significant result. In addition, Gupta [15] studied the principal determinants of tax revenue performance across developing countries by using a broad dataset of 105 countries over 25 years. In his study, he noted that per capita GDP, agriculture share in GDP, trade openness, foreign aid, corruption, political stability, the share of direct and indirect taxes were significant in determining revenue performance. The paper stated that revenue collections are low in countries, which heavily depend upon taxing goods and services, while countries that levy taxes on income, profits and capital gains have high outturn of revenue.

A study by Mahdavi [4] used an unbalanced panel data for 43 developing countries over the period 1973-2002. 
His results showed that Foreign Aid had a negative effect, non-tax revenue had also negative effect while agriculture sector share had positive but insignificant coefficient. Trade sector share had a positive effect and economically active female variable had a net adverse but insignificant effect while the old-age portion of population showed negative association for both income and sales tax. Extent of urbanization and literacy rate both showed positive effect. Population density, monetization and inflation rate remained negatively correlated. Inverse of GDP per capita was strongly and negatively correlated with the level of taxation. Net effect of political rights and civil liberties was significant. Another study by Keen and Mansour [22] provide a broad picture of revenue developments in the African region between 1980 and 2005. The study finds that countries' experiences have varied, but the overall picture is of non-resource revenues having been essentially stagnant. Within this, however, and with exceptions, reductions in trade tax revenue have been largely offset by increased revenue from domestic sources.

While, Blejer and Cheasty [2] examined the determinants of tax buoyancy of 25 developing countries by using the cross section data for the year 1998 to 2008 and pooled least square method for result analysis. For agriculture sector it showed insignificant effect and for services sector it showed positive and significant effect instead of past insignificant result of many researches. Monetization and budget deficit showed positive influence while growth in grants showed negative impact on tax buoyancy.

Among the studies conducted on tax performance for Uganda is a study by Hisali [23]. He examined the tax system and tax structure of Uganda to investigate the factors effecting tax revenue in the country. He used the time series data of the period 1970 to 2000 and estimated a model. His results showed that agriculture ratio, population density and tax evasion affect all type of taxes. GDP per capita showed the surprising negative sign. Tax evasion and openness as measured by import ratio showed the significant negative impact. Aid variable showed positive sign since Aid in Uganda always supported imports especially raw material so not surprisingly.

A study by Keen and Mansour [22] looks at the relationship between tariff reform and customs tax revenue by explicitly capturing the institutional features of decision making in the econometric modelling. The study uses the Johansen multivariate approach and Error Correction Model to establish the long run and short relationship between trade tax revenue and tax performance. The results show that exchange rate depreciation has pass through effects to the domestic market price of imports which reduces trade tax revenue to GDP ratio in the long run, though it increases trade tax revenue in the short term.

Generally literature shows that several studies attempt to establish determinants of tax revenue performance in developing countries by the traditional regression approach, stochastic frontier analysis and deviations approach as discussed in the theoretical literature.

\section{Methodology, Results and Conclusions}

Tax revenue performance remains an important area of study for many low incomes experiencing low tax revenue performance. In Uganda, tax revenue has increased as a percentage of GDP, but the government's expenditure as a percentage of GDP has been far higher than that of the tax revenue collections (Figure 3). This implies

Revenue \& Expenditure as a \% of GDP

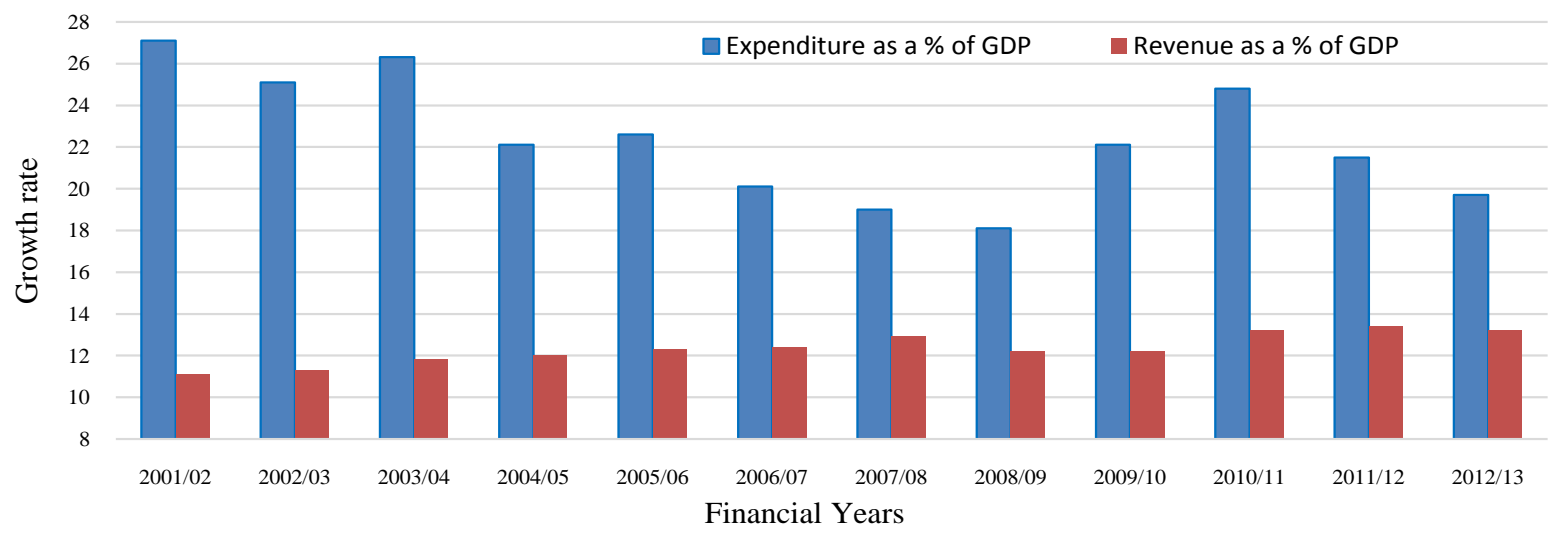

Figure 3. Government revenue and expenditure as a percentage of GDP. Source: Author's computation based on the World Bank’s World Development Indicators (WDI) database and MFPED Background to the Budget various years 2000 to 2012. 
that tax revenue outturn remains inadequate to finance government budget. For example, from 2000 to 2012 , the tax revenue GDP ratio averaged at 13.18 percent compared to the East Africa countries average of about 18.1 percent (Figure 2). If the East African countries average is a calibration to go with, then it suggests that the contributions of tax revenue to GDP in Uganda are not performing well. Based on this tax revenue performance, it's important to establish the determinants of tax revenue performance in recent years under a more liberalized trade regime.

\subsection{Methodology}

A considerable number of studies have attempted to evaluate tax revenue performance in different countries. The studies have looked at the tax ratio as a measure of countries relative tax revenue performance. Among early studies on tax revenue performance is a study by Musgrave [12], he provides an explanation as to why low income countries seem to have a lower levels of tax revenue as compared to high income countries. Musgrave presents a key term of tax handles to describe the taxable capacity of a country. He provides an explanation that it's more difficult to impose and collect taxes in low income countries than in high income countries. He reasons that it is not only the skills and facilities of tax administration in those countries that are less developed, but also the structure of low income countries can only afford a fewer tax handles on which to collect taxes. Thus, the relative absence of adequate tax handles in low income countries is the main reason why their tax to GDP ratios is lower than those of high income countries.

Analysis of existing literature by Bahl, Lotz and Morss, Gupta, Stotsky and WoldeMariam, Khattry and Rao, Tanzi and Blejer ([13]-[15] [18] [24] [25]) further reveals that the studies looking at tax performance have used a variety of methods to estimate tax revenue performance. The most commonly used approach is the behavioral approach or to regress the tax performance on variables that serve as proxies for a country's tax performance. This means that the dependent variables in the regression analysis is taken as tax revenue performance while the variable that serve as proxies for a country's tax revenue performance are taken as independent variables. The approach was proposed by Bahl [13] and Chelliah et al. [21] to measure tax revenue performance, the approach is used to regress the tax revenue GDP ratio on a set of variables that serve as proxies for a country's tax handles. The set of variables include the major determinants of output of a country. In a functional form, it is represented below.

$$
T / Y=f(V)
$$

where,

$$
\begin{aligned}
& T=\text { Tax revenue } \\
& Y=\text { GDP or GNP } \\
& T / Y=\text { Tax revenue GDP ratio } \\
& V=\text { Vector of tax handles. }
\end{aligned}
$$

The equation provides an average relationship between the tax revenue GDP ratio and the set of explanatory variables chosen and hence, the predicted tax revenue GDP ratio gives the ratio that the country would have if it had made the average tax effort. Thus the predicted tax revenue GDP ratio is interpreted as a measure of taxable capacity while the regression coefficients act as the average effective rates on the bases. According to work by Bahl, Lotz and Morss, Gupta, Stotsky and WoldeMariam, Khattry and Rao, Tanzi and Blejer ([13]-[15] [18] [24] [25]), we modify equations of Bahl [13] and Chelliah et al. [21] into Equation (4.1).

$$
T_{i t} / Y_{i t}=f\left(X_{1 t}, X_{2 t}, \cdots, U_{i t}\right)
$$

where $T_{i t}$ is the tax performance variable representing total tax, indirect tax, direct tax and international trade tax revenue, $Y_{i t}$ is a proxy for income in this study GDP and $T_{i t} / Y_{i t}$ is the tax revenue performance. The independent variables which are expected to influence the tax revenue performance are represented by $X_{i t}$ (where $i=1,2,3, \cdots, n$ ), with $t$ representing different time periods while $U_{i t}$ is the error term. This is expressed in the following functional relationship. The choice of variable is discussed and presented below.

$$
T_{i t} / Y_{i t}=f\left(\mathrm{GDP}_{i t}, \mathrm{AGR}_{i t}, \mathrm{FDI}_{i t}, \mathrm{OPEN}_{i t}, \mathrm{EXR}_{i t}, \mathrm{DEBT}_{i t}, \mathrm{AID}_{i t}, \mathrm{ATR}_{i t}, \cdots\right)
$$

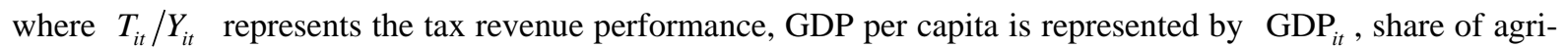
cultural sector in GDP is represented by $\mathrm{AGR}_{i t}$, GNE represents government expenditure, IND represents industry share in GDP, share of FDI to GDP is $\mathrm{FDI}_{i t}, \mathrm{OPEN}_{i t}$ is the degree of trade openness measured by imports and exports divided by GDP, $\mathrm{AID}_{i t}$ is aid per capita, $\mathrm{DEBT}_{i t}$ is debt per capita, EXR $\mathrm{EX}_{i t}$ is the ex- 
change rate and $\mathrm{ATR}_{i t}$ is average tax rate. The structural model is presented below.

$$
T_{i t} / Y_{i t}=\beta_{0}+\beta X_{i t}+\varepsilon_{i t}
$$

The $\left(T_{i t} / Y_{i t}\right)$ represents the tax revenue performance, this model has a constant term $\left(\beta_{0}\right)$ and $X_{i t}$ representing a set of control variables for the seven low income countries over an 18 year time period. The determinants of tax revenue performance are empirically analyzed by regressing the share of tax revenue in GDP on the natural log of real per capita GDP, share of agricultural in GDP, share of FDI to GDP, index of openness, average tariff rates and exchange rate. These variables are entered in logarithms, while Aid per capita, Debt per capita and consumer price index are entered linearly. The equation is then represented as below.

$$
\begin{aligned}
T_{i t} / Y_{i t}= & \beta_{0}+\beta_{1} \mathrm{GDP}_{i t}+\beta_{2} \mathrm{AGR}_{i t}+\beta_{3} \mathrm{FDI}_{i t}+\beta_{4} \mathrm{OPEN}_{i t}+\beta_{5} \mathrm{EXR}_{i t}+\beta_{6} \mathrm{PCDEBT}_{i t}+\beta_{7} \mathrm{PCAID}_{i t}+\beta_{8} \mathrm{ATR}_{i t} \\
& +\beta_{9} \mathrm{GNE}_{i t}+\beta_{10} \mathrm{IND}_{i t}+U_{i t} .
\end{aligned}
$$

\subsubsection{Choice of Independent Variables}

The variables used in this study are drawn from literature and are presented below, the variable are selected owing to their ability to influence the level of tax revenue performance. The following is the list of the selected independent variables that have been suggested by economic theory and previous empirical studies.

Level of Economic Development: this is measured by GDP per capita. Higher incomes countries reflect a higher level of development, which is usually associated with a higher ability for tax payers to pay taxes as well as a greater capacity of the government to collect taxes; while low income countries reflect a lower level of development, which is usually associated with a lower ability of tax payers to pay taxes as well as governments' ability to collect taxes. Higher income countries tend to have a higher degree of monetization of the economy and better tax administration compared to lower income countries [26]. Higher income countries often tax more progressively as compared to lower income countries. Therefore, it is expected that there is a positive relationship between the tax performance and GDP per capita. In the model an increase in GDP per capita is expected to lead to an increase in tax performance. Therefore increasing GDP is expected to have positive relationship with tax revenue performance. In addition, government expenditure is expected to have a positive relation with tax revenue performance.

Composition of GDP: this measures the share of the agricultural sector in GDP, the share of the agricultural sector in GDP is used for reflecting the ease or difficulty of taxing different structures in the economy. The agricultural sector is big in most low income countries and its activities are subsistence in nature. From a taxation point of view taxing the agricultural sector in low income countries requires reorganizing their activities into small and medium enterprises. Agriculture sector activities are usually exempted from taxes in order to make the tax regimes more progressive to the poor. In addition, the agricultural sector reflects a possible degree of tax evasion in the economy. Thus, the share of agriculture in GDP is expected to be negatively related with tax performance. By contrast, higher income countries usually show a large share of industrial sector in their GDP. The industrial sector is relatively easy to tax compared to the agricultural sector, the industrial sector yields a larger amount of tax revenue for developed countries compared to the agricultural sector [15]. Therefore, a higher share of the agricultural sector is expected to have a negative impact on tax performance. In addition composition of the industrial sector to GDP is expected to have a positive relation with tax revenue performance.

Openness: this is measured as the ratio of imports and exports of goods and services to GDP. Openness has largely been considered a fundamental determinant of taxable capacity by different studies. Among the studies that have presented the importance of openness are studies by Lotz and Morss [14] and Wibbels and Moisés [27]. These studies use the ratio of trade to GDP to estimate the degree of globalization, the level of trade barriers and the extent of a country's foreign trade sector to explain the level of openness among different countries. Although it is quite difficult to assess the direct impact of openness on tax revenues, openness may influence taxation indirectly by affecting many economic variables which in turn affect tax revenue. Some studies finding a strong association between the degree of openness and tax revenue include [9] [26] [28]-[31]. Given that tax revenues of low income countries, especially from a trade tax perspective, tend to have high dependency on the international trade sector, an increase in the degree of trade openness is expected to bring higher tax revenue. Thus, a positive relationship is expected between higher levels openness and tax performance.

Public Debt: this is measured in terms of debt per capita. A high level of government expenditure often leads to large fiscal deficits. The deficit in most cases is covered by grants and loans which increases the public debt. 
The negative relationship between debt and tax performance has been noted by Tanzi and Blejer [25] who find that high government expenditure often leads to an increase in public debt. The public debt often comes at concessional and non-concessional interest rates. Therefore it is expected that public debt is negatively related to total tax revenue.

Transfer of Aid: this is measured in terms of aid per capita. Foreign aid has also been identified as a factor that may affect revenue performance. A key distinction appears to be whether the aid is used productively or simply to finance current consumption expenditures. Moreover, the composition of aid has an important effect on revenue performance. For example, Gupta [15] finds that concessional loans are associated with higher revenue mobilization, while grants have the opposite effect. Studies by Brownbridge and Tumusiime-Mutebile [6] and Maren [32] find that aid could lead to a decrease in tax revenues performance. Therefore, aid is expected to have a negative relationship with tax performance. On the other hand studies by Khattry and Rao [24] and Wacziarg and Welch [33] find that Aid could lead to an increase tax performance hence a positive relationship. Therefore we expect either a negative or a positive relationship.

FDI: several studies state that foreign investment is sensitive to tax rate differences [15]. Thus, the investments in higher-tax countries are shifting toward low-tax countries, which are expected to increase revenues in low income countries. Additionally, it could be considered a proxy to the ability of multinational firms to respond to international tax incentives. Therefore, FDI is expected to have a positive relationship with tax performance [15] [34].

Exchange rate: a depreciation of exchange rate is expected to lead to an increase in import volumes. Since a larger part of low income countries rely on tariff revenue, depreciation is expected to increase tariff revenue. However on the other hand currency appreciation could potentially lead to a lower volume of imports and lower tariff revenue. According to Khattry and Rao [24] a negative relationship is expected between exchange rates and trade taxes. A recent study by Hisali [23] finds that exchange rate depreciation and appreciation could lead to an increase tax performance for Uganda. Therefore a positive relationship is expected between tax revenue performance and exchange rate.

Inflation: this is measured by the consumer price index. Inflation leads to an increase in a countries nominal income through increasing their purchasing power. It presents an illusion of increased disposable incomes to consumers. Inflation increases the purchasing power of consumer through increasing demand for goods and services. Therefore it is assumed that inflation is positively related to tax revenue. Studies by Tanzi and Blejer [25] suggest that inflation will increase the tax base for tax revenue. Therefore we expect a positive relationship between inflation and tax performance.

Average tariff rates: the relationship between average tariff rates and tax revenue is assumed to be nonlinear since it is expected to capture the existence of Laffer curve. By including the average tariff rate as an explanatory variable for tax revenue performance, it helps us investigate whether a further reduction in tariff rate results in the decrease in trade tax revenue. In this study we use average tariff rates as a proxy for trade liberalization. This is in line with other studies that have attempted to investigate the effects of tariff liberalization on tax revenue. Some of the studies that have used average tariff rates as a proxy for trade liberalization include [24] [26]. The studies support the idea that tariff liberalization increase tax revenue performance, therefore a positive relationship is expected between average tariff rates and tax revenue.

\subsubsection{Data}

Empirical studies assessing the effect of tariff liberalization on tax revenues use either cross-country studies or individual-country studies data. This study adopts a cross-country study using fixed effects and random effects estimations to establish the determinants of tax revenue performance. This study uses panel data for Uganda and its six key trading partners Burundi, Kenya, Rwanda, Tanzania, Sudan and DRC the panel for the countries is taken over an 18 years period from 1994 to 2012.

\subsubsection{Data Analysis Technique}

To decide between fixed or random effects, we run a Hausman test. The null hypothesis is that the preferred model is fixed effects against the alternative that it's not the preferred model. The Hausman test tests the null hypothesis that the coefficients estimated by the efficient fixed effects estimator are the same as the ones estimated by the inconsistent random effects estimator. If they are insignificant, i.e. Probability $>$ chi2 larger than 0.05 , then it is safe to use random effects. If we get a significant P-value less than 0.05 , we use fixed effects. We 
run a fixed effects model and save the estimates, then run a random model and save the estimates, we then perform the Hausman test. The Hausman test is performed for all the models the total revenue models, indirect taxes models, direct taxes model and international trade model. If the estimated Prob > chi2 is smaller than 0.05, this means that the P-value is significant as a result we use the fixed effects model. On the other hand, if it's greater than 0.05 this means the P-value is insignificant and as a result we use the random effects model. Prior to estimating of the model in Equation 4.3, test are performed to test for stationarity of the variables, a panel unit root test is done following a methodology laid down by works of Dickeyand Fuller [35]. The results indicate that all variables are stationary at level (Table 1). Estimations are performed using Stata 11 Econometric Software Package.

\subsection{Results}

This section reports the results of estimating Equation (4.4), the model presents several independent variables but the discussion mainly focuses on the variables of key interest. Variables with significant results are singled out for analysis. The overall results are presented in Tables 2-5 representing total tax revenue, indirect taxes revenue, direct taxes revenue and international trade tax revenue.

\subsubsection{Discussion of Determinants of Indirect Tax Revenue}

Table 2 reports the results for the determinants of indirect tax revenue, the Hausman test is performed on the estimated indirect taxes models, the results show that the estimated Probability $>$ chi2 is smaller than 0.05 , which means that the P-value is significant as a result we use the fixed effects model. Equations (4.1)-(4.3) are presented, however, Equation (4.1) is singled out for detailed analysis.

The coefficient for GDP or income has a positive sign in our regression indicating that indirect taxes tax to GDP ratio increases with an increase of income. The coefficient is statistical significant at 5 percent level of significance. The result is in line with the expected sign where GDP is associated with economic development, government's ability to collect taxes and citizen's ability to pay taxes [15].

The results for the nominal exchange rate show a negative relationship with indirect tax revenue performance. The coefficient is statistical significant at 5 percent level of significance. The negative relationship between in-

\section{Table 1. Description of the data set used in the analysis.}

\begin{tabular}{|c|c|}
\hline Variable & Source \\
\hline Total tax revenue GDP ratio & World Bank, World Development Indicators (WDI), July 2013. \\
\hline Indirect tax revenue GDP ratio & Africa Economic Outlook, Statistical Annex, April 2014 \\
\hline Direct tax revenue GDP ratio & Africa Economic Outlook, Statistical Annex, April 2014 \\
\hline International trade tax revenue GDP ratio & Africa Economic Outlook, Statistical Annex, April 2014 \\
\hline GDP per capita (GDP) & World Bank, World Development Indicators (WDI), July 2013. \\
\hline Share of agricultural sector in GDP (AGR) & World Bank, World Development Indicators (WDI), July 2013. \\
\hline Share of FDI to GDP (FDI) & World Bank, World Development Indicators (WDI), July 2013. \\
\hline Imports (M) of goods and services; & $\begin{array}{l}\text { Constant } 2000 \text { Local Currencies, Source; World Bank, World Development } \\
\text { Indicators (WDI), July } 2013\end{array}$ \\
\hline Exports (EXP) of goods and services & $\begin{array}{l}\text { Constant } 2000 \text { Local Currencies, Source; World Bank, World Development } \\
\text { Indicators (WDI), July } 2013\end{array}$ \\
\hline $\begin{array}{l}\text { Trade Openness is the degree of trade openness } \\
\text { measured by imports and exports divided by GDP }\end{array}$ & $\begin{array}{l}\text { Author's computation July 2013. Data on Imports (M) AND Exports (X) of } \\
\text { Goods and Services; Source; World Bank, World Development Indicators } \\
\text { (WDI), July } 2013\end{array}$ \\
\hline PCAID is aid per capita & World Bank, World Development Indicators (WDI), July 2013. \\
\hline Gross national expenditure (\% of GDP) & World Bank, World Development Indicators (WDI), July 2013. \\
\hline Industry, value added (\% of GDP) & World Bank, World Development Indicators (WDI), July 2013. \\
\hline EXR is the exchange rate & IMF’s International Financial Statistics (IFS), July 2013. \\
\hline Average tariff rate & World Bank, World Development Indicators (WDI), July 2013. \\
\hline Consumer price index (INF) & IMF’s International Financial Statistics (IFS), July 2013. \\
\hline
\end{tabular}


Table 2. Determinants of indirect tax revenue.

\begin{tabular}{|c|c|c|c|}
\hline & Equation (4.1) & Equation (4.2) & Equation (4.3) \\
\hline \multirow[t]{2}{*}{ Constant } & 1.983 & 1.681 & 3.644 \\
\hline & $(0.799)$ & (1.009) & $(0.759)$ \\
\hline \multirow[t]{2}{*}{ GDP per capita } & 0.003 & 0.002 & \\
\hline & $(0.001)$ & $(0.001)$ & \\
\hline \multirow[t]{2}{*}{ Exchange rate } & -0.004 & -0.003 & -0.002 \\
\hline & $(0.001)$ & $(0.001)$ & $(0.001)$ \\
\hline \multirow[t]{2}{*}{ Trade openness (\% GDP) } & 0.025 & 0.042 & 0.030 \\
\hline & $(0.009)$ & $(0.011)$ & $(0.011)$ \\
\hline \multirow[t]{2}{*}{ FDI (\% of GDP) } & 0.143 & 0.108 & 0.108 \\
\hline & $(0.040)$ & $(0.050)$ & $(0.054)$ \\
\hline \multirow[t]{2}{*}{ Inflation } & -0.004 & & \\
\hline & $(0.002)$ & & \\
\hline \multirow[t]{2}{*}{ Tariff rate, all products (\%) } & -0.082 & -0.065 & -0.069 \\
\hline & $(0.026)$ & $(0.032)$ & $(0.034)$ \\
\hline \multirow[t]{2}{*}{ AID (\% of GDP) } & 0.017 & 0.012 & \\
\hline & $(0.003)$ & $(0.004)$ & \\
\hline Observation & 78 & 80 & 81 \\
\hline R-squared & 0.66 & 0.54 & 0.42 \\
\hline
\end{tabular}

Source: Author's computation. Variables are statistically significant at $5 \%$ level of significance. Standard errors are reported below the coefficients in parentheses.

Table 3. Determinants of direct tax revenue.

\begin{tabular}{|c|c|c|c|}
\hline & Equation (4.1) & Equation (4.2) & Equation (4.3) \\
\hline \multirow[t]{2}{*}{ Constant } & -34.330 & -36.549 & -14.410 \\
\hline & $(8.372)$ & $(8.468)$ & $(5.623)$ \\
\hline \multirow[t]{2}{*}{ Gross national expenditure (\% of GDP) } & 0.236 & 0.285 & 0.192 \\
\hline & $(0.066)$ & $(0.062)$ & $(0.046)$ \\
\hline \multirow[t]{2}{*}{ Industry, value added (\% of GDP) } & 0.271 & 0.264 & \\
\hline & $(0.100)$ & $(0.124)$ & \\
\hline \multirow[t]{2}{*}{ Trade openness (\% GDP) } & 0.046 & & \\
\hline & $(0.023)$ & & \\
\hline \multirow[t]{2}{*}{ Share of agriculture to GDP } & & & -0.096 \\
\hline & & & $(0.050)$ \\
\hline \multirow[t]{2}{*}{ Tariff rate, all products (\%) } & 0.180 & 0.207 & \\
\hline & $(0.091)$ & $(0.092)$ & \\
\hline \multirow[t]{2}{*}{ AID (\% of GDP) } & 0.035 & 0.022 & 0.011 \\
\hline & $(0.011)$ & $(0.009)$ & $(0.007)$ \\
\hline Observation & 83 & 83 & 109 \\
\hline R-squared & 0.49 & 0.45 & 0.38 \\
\hline
\end{tabular}

Source: Author's computation. Variables are statistically significant at 5\% level of significance. Standard errors are reported below the coefficients in parentheses. 
Table 4. Determinants of international trade tax revenue.

\begin{tabular}{|c|c|c|c|}
\hline & Equation (4.1) & Equation (4.2) & Equation (4.3) \\
\hline \multirow[t]{2}{*}{ Constant } & -1.492 & -1.782 & -2.075 \\
\hline & $(0.523)$ & $(0.520)$ & $(0.573)$ \\
\hline \multirow[t]{2}{*}{ Exchange rate } & -0.001 & & \\
\hline & $(0.000)$ & & \\
\hline \multirow[t]{2}{*}{ Trade openness (\% GDP) } & 0.030 & 0.030 & 0.038 \\
\hline & $(0.006)$ & $(0.007)$ & $(0.007)$ \\
\hline \multirow[t]{2}{*}{ FDI (\% of GDP) } & 0.088 & 0.065 & 0.061 \\
\hline & $(0.029)$ & $(0.027)$ & $(0.030)$ \\
\hline \multirow[t]{2}{*}{ Inflation } & -0.003 & -0.003 & \\
\hline & $(0.002)$ & $(0.002)$ & \\
\hline \multirow[t]{2}{*}{ Tariff rate, all products (\%) } & 0.041 & 0.038 & 0.038 \\
\hline & $(0.019)$ & $(0.020)$ & $(0.021)$ \\
\hline \multirow[t]{2}{*}{ AID (\% of GDP) } & 0.010 & 0.010 & 0.010 \\
\hline & $(0.002)$ & $(0.002)$ & $(0.002)$ \\
\hline Observation & 77 & 77 & 79 \\
\hline R-squared & 0.64 & 0.61 & 0.61 \\
\hline
\end{tabular}

Source: Author's computation. Variables are statistically significant at 5\% level of significance. Standard errors are report below the coefficients in parentheses.

Table 5. Determinants of total tax revenue.

\begin{tabular}{cccc}
\hline & Equation (4.1) & Equation (4.2) & Equation (4.3) \\
\hline Constant & 17.459 & 21.950 & $(3.551)$ \\
Exchange rate & $(3.632)$ & $(3.406)$ & \\
& 0.006 & & 0.120 \\
Trade openness (\% GDP) & $($ ) 0.002 & 0.154 & $(0.031)$ \\
Share of agriculture to GDP & 0.117 & $(0.027)$ & -0.262 \\
AID (\% of GDP) & $(0.029)$ & -0.231 & $(0.078)$ \\
Observation & -0.151 & $(0.076)$ & -0.020 \\
R-squared & $(0.078)$ & -0.021 & $(0.011)$ \\
\hline
\end{tabular}

Source: Author's computation. Variables are statistically significant at 5\% level of significance. Standard errors are reported below the coefficients in parentheses.

direct tax revenue performance and the nominal exchange rate, suggests that an increase in exchange rate variable causes a reduction in indirect tax revenue performance. Normally it is expected that nominal exchange rate is associated with a positive sign which leads to an increase in indirect tax revenue performance. The positive sign is intended to make the price of exports more competitive on the international market. However, small open countries like Uganda the results are reasonable. This is because these countries are exposed to economic shocks that affect foreign earnings and overall foreign exchange reserve. The shocks appreciate the exchange rate thereby 
creating a negative sign for exchange rate. Therefore a negative relationship is also likely for small open economies.

The results for trade openness suggest a significant positive relationship with indirect tax revenue performance at 5 percent level of significance. The results coincide with economic theory and empirical evidence, which predict that trade liberalization leads countries to have higher trade volumes and increase in tax revenue performance. The possible explanation for the positive result is that trade openness increases access to consumer goods, intermediate imports and export markets which combine to improve indirect taxes particularly VAT and Excise tax.

The results for FDI and Aid are in line with study predictions and suggest a significant positive relationship with indirect tax revenue performance. Aid and FDI directly increase consumption taxes such as VAT and Excise duties. Consumption taxes are mainly paid by the final consumer which explains the positive relationship between FDI/Aid and indirect tax revenue performance. Inflation has a negative relationship with indirect tax revenue performance. The coefficient is statistical significant at 5 percent level of significance. Suggesting that an increase in inflation causes a reduction in indirect tax revenue performance, the possible explanation for the negative relationship is that when prices increase consumption for goods and services decrease which directly reduces consumption taxes. This is in line with economic theory which suggests that an increase in prices causes reduction consumptions levels which consequently affect tax revenue performance. Lastly the result for the average tariff rate has a negative relationship with indirect tax revenue performance. The coefficient is statistical significant at 5 percent level of significance indicating that a reduction in the average tariff rate causes a decline in indirect tax revenue performance.

\subsubsection{Discussion of Determinants of Direct Tax Revenue}

Table 3 reports the results for the determinants of direct tax revenue. The Hausman test is performed on the estimated direct taxes models, the results show that the estimated Probability $>$ chi2 is smaller than 0.05 , which means that the P-value is significant as a result the fixed effects model is the preferred model. Equations (4.1)-(4.3) are presented however Equation (4.1) is singled out for detailed analysis.

The relationship between the direct tax revenue and the average tariff rate is positive. The relationship between direct tax revenue and industry share to GDP demonstrates a positive relationship. Trade openness which captures the influence of trade liberalization on direct tax revenue performance is positive. In all the three cases the coefficients are statistical significant at 5 percent level of significance. The findings suggest that average tariff rate, share of industry to GDP and trade openness increase direct tax revenue performance.

The possible explanation for the positive sign between direct taxes and the average tariff rate is that an increase in the average tariff rates is likely to increase corporate taxes and individual incomes taxes. The positive relationship between industry share to GDP and direct tax revenue also suggests that an increase in the number of industrial enterprises is likely to increase corporate taxes and individual incomes taxes. The positive relationship for trade openness coincides with economic theory and empirical evidence, which predicts that trade liberalization leads countries to have higher trade volumes which consequently increase corporate and individual incomes taxes. This result is in line with the previous literature by Slemrod [34]. Lastly, Aid which capture the influence of public expenditure on direct tax revenue performance is positive and statistical significant at 5 percent level of significance. The results for aid indicate that a higher stock of government expenditure through aid increases the ratio of direct tax revenue to GDP. The result on Aid is in line with the previous studies by Slemrod [34] who finds a similar relationship for selected developing countries.

\subsubsection{Discussion of Determinants of International Trade Tax Revenue}

Table 4 reports the results for the determinants of international trade tax revenue. The Hausman test is performed on the estimated international trade tax revenue models, the results show that the estimated Probability $>$ chi2 is smaller than 0.05 , which means that the P-value is significant as a result the fixed effects model is used. Equations (4.1)-(4.3) are presented however Equation (4.1) is singled out for detailed analysis.

The coefficient for the nominal exchange rate shows a negative relationship with international trade tax revenue performance. The result is statistical significant at 5 percent level of significance. The negative relationship between international trade tax revenue performance and the nominal exchange rate suggests that an increase in exchange rate causes a reduction in international trade tax revenue performance.

Another international trade factor, trade openness, suggests a significant positive relationship with interna- 
tional trade tax revenue performance. The coefficient is statistical significant at 5 percent level of significance. The result coincides with economic theory and empirical evidence, which predicts that trade liberalization leads countries to have higher trade volumes and increase in international trade tax base. The results for FDI and Aid, suggests a significant positive relationship with international trade tax revenue performance. Aid and FDI increases the volumes of imports which increase a broad array of international trade taxes such as Import duty, VAT and Excise duties.

The result for inflation has a negative relationship with international trade tax revenue performance, the coefficient is statistical significant at 5 percent level of significance. This suggests that inflation causes a reduction in international trade tax revenue performance. The possible explanation is that when prices increase the tax base for international trade taxes declines through lower importation of goods and services. This is in line with economic theory which suggests that an increase in prices causes a reduction in goods and services consumed.

Lastly the result for the average tariff rate has a positive relationship with international trade tax revenue performance. The coefficient is statistical significant at 5 percent level of significance. This suggests that an increase in the average tariff rate increases international trade tax revenue performance. This is in line with economic theory and the study's prediction.

\subsubsection{Discussion of Determinants of Total Tax Revenue}

Table 5 reports the results for the determinants of total tax revenue using a fixed effects model. The results of the estimated coefficients for the explanatory variables are reported under this table. The results suggest that factors specific to these countries are important determinants of variations in total tax revenue performance. The results are in line with the study predictions and coincide with previous findings in tax performance literature. Equations (4.1)-(4.3) are presented however Equation (4.1) is singled out for detailed analysis.

The results for the nominal exchange rate show a significant positive relationship with total tax revenue performance. The positive relationship between total tax revenue performance and the nominal exchange rate, suggests that an increase in exchange rate causes a growth total tax revenue performance. A probable explanation for this is that local currencies in developing countries are often associated with depreciations. The depreciation is intended to make the price of exports of these countries more competitive on the international market. The outcome of currency depreciation is an increase in the direct and indirect tax bases through increases in producer earnings from exports. For example Uganda has undertaken several currency depreciations over the period to enhance competitiveness of the economy [7]. The results are similar to result by Khattry and Rao [24] who finds that exchange rate depreciation could lead to an increase tax revenue performance.

The results for trade openness, suggests a significant positive relationship with tax revenue performance, indicating that the more a country trades with other countries, the higher tax revenue the country collects. The significantly positive relationship between openness and the tax GDP ratio is obtained from taxes on exports and imports of country. Low income countries heavily rely on taxes on import and export because they are relatively easier to assess and enforce than domestic taxes, as monitoring the entry and exit of goods into and from the country is generally straightforward. The result is in line with study predictions and coincides with economic theory and empirical evidence, which predicts that trade liberalization leads countries to have higher trade volumes and increase in tax revenue performance [24] [27].

The estimated coefficients for the share of the agricultural sector in GDP are significant and suggest a negative relationship with tax revenue performance. Several factors contribute to this result: Firstly, a large part of the agricultural sector is small-scale with limited number of taxpayers paying tax on income or profits. Secondly, a substantial part of the output is consumed and not marketed. Thirdly, marketed agricultural products are to a large extent exempted from indirect taxation. Finally, the cost of verification of actual income is very high. A large share of agricultural products is also exempted from indirect taxes. The above reasons explain the negative relationship between the shares of agriculture in GDP and tax revenue performance. The results are in line with the study predictions and coincide with previous findings by Gupta [15], Stotsky and WoldeMariam [18], Wacziarg and Welch [36], Teera [37] who find that the share of the agricultural sector in GDP has a negative relationship with tax revenue performance.

The results for foreign aid have a significant positive effect on total tax revenue performance. For low income countries, an increase in foreign aid improves total tax revenue performance, this relationship is statistically significant at 5 percent level of significance. The results are in line with the expected signs and are supported using studies by Hisali [23] who finds that Aid could lead to an increase tax revenue performance. 
Lastly the result for inflation has a negative relationship with total tax revenue performance. The coefficient is statistical significant at 5 percent level of significance. An increase in prices decreases total tax revenue performance. The possible explanation is that an increase in inflation reduces profitability of companies as well as consumption of goods and services which directly reduces direct taxes and consumption taxes. This is in line with economic theory and study predictions.

\subsection{Conclusions}

This study has attempted to identify the determinants of tax revenue performance over the past 18 years in Uganda. The study investigates determinants for indirect taxes, direct taxes, international trade tax revenue as well as the aggregate total tax revenue performance. The structural variables show that income (GDP), the share of agriculture to GDP and share of industry to GDP are statistically significant and determine tax revenue performance with expected signs of the estimated coefficients. The international factors such as trade openness, exchange rate and FDI are statistically significant and determine tax revenue performance with expected signs on the estimated coefficients. We included institutional variables such as average tariff rate, inflation and government expenditure. The variables are statistically significant and determine tax revenue performance with expected signs.

We establish that all the analyzed variables play an important role in determining the tax revenue ratio. It is generally acknowledged that the list of factors that could potentially explain the tax revenue performance is extensive, and our analysis only examines some of them.

\subsection{Policy Implications}

The results bear out policy implications, the significant positive association between trade openness and tax revenue suggests that policies which increase the level of trade openness will be effective on increasing tax revenue for direct, indirect and international trade tax revenue. This result reveals that the tax bases for Uganda's domestic tax sources improved after trade openness. Therefore, in order to improve revenue productivity, the government should implement policies to enhance tax compliance in domestic taxes.

\section{Acknowledgements}

I would like to express my gratitude to Associate Professors Eria Hisali and Edward Bbaale for the very helpful comments and constructive suggestions on econometric analysis.

\section{References}

[1] Li, X.M. (2004) Trade Liberalization and Real Exchange Rate Movement. IMF Staff Papers, 51, 553-584.

[2] Blejer, M. and Cheasty, A. (1990) Fiscal Implications of Trade Liberalization. In: Tanzi, V., Ed., Fiscal Policy in Open Developing Economies, International Monetary Fund, Washington DC, 66-81.

[3] Tanzi, V. (1989) The Impact of Macroeconomic Policies on the Level of Taxation and the Fiscal Balance in Developing Countries. IMF Staff Papers, 36, 633-656. http://dx.doi.org/10.2307/3867050

[4] Mahdavi, S. (2008) The Level and Composition of Tax Revenue in Developing Countries: Evidence from Unbalanced Panel Data. International Review of Economics and Finance, 17,607-617. http://dx.doi.org/10.1016/j.iref.2008.01.001

[5] Tanzi, V. (2003) Trade Liberalization and Trade Taxes, Integration, Trade and Hemispheric Issues Division, Integration and regional Programs Department. A Note Prepared for the Meeting of Trade and Integration Network, 14-15 August 2003.

[6] Brownbridge, M. and Tumusiime-Mutebile, E. (2006) Aid and Fiscal Deficits: Lessons from Uganda on the Implications for Macroeconomic Management and Fiscal Sustainability. Development Policy Review, 25,193-213. http://dx.doi.org/10.1111/j.1467-7679.2007.00366.x

[7] Cawley, G. and Zake, J. (2010) Tax Reforms, Uganda Economic Reforms: Insider Accounts. Oxford University Press, 103.

[8] Harvey, S. and Sedegah, K. (2011) Import Demand in Ghana: Structure, Behaviour and Stability. AERC Research Paper No. 233.

[9] Ebrill, L, Stotsky, J. and Gropp, R. (1999) Revenue Implication of Trade Liberalization. IMF Occasional Paper No. 180.

[10] Summers, L. (1991) Regionalism and the World Trading System. Policy Implications of Trade and Currency Zones. 
Federal Reserve Bank of Kansas City, Kansas City.

[11] Wonnacott, P. and Lutz, M. (1989) Is There a Case for Free Trade Areas? In: Schott, J., Ed., Free Trade Areas and U.S. Trade Policy, Institute of International Economics, Washington DC, 59-84.

[12] Musgrave, R.A. (1969) Fiscal Systems. Yale University Press, New Haven.

[13] Bahl, R.W. (1972) Alternative Methods for Tax Revenue Forecasting in Developing Countries: A Conceptual Analysis. IMF Unpublished Paper.

[14] Lotz, J.R. and Morss, E.R. (1970) A Theory of Tax Level Determinants for Developing Countries. Economic Development and Cultural Change, 18, 328-341. http://dx.doi.org/10.1086/450436

[15] Gupta, A. (2007) Determinants of Tax Revenue Efforts in Developing Countries. IMF Working Paper No. WP/07/184.

[16] Glenday, G. (2002) Trade Liberalization and Customs Revenues: Does Trade Liberalization Lead to Lower Customs Revenues? The Case of Kenya. Journal of African Finance and Economic Development, 5, 89-125.

[17] Krugman, P. (1991) The Move to Free Trade Zones. Policy Implications of Trade and Currency Zones. Federal Reserve Bank of Kansas City, Kansas City.

[18] Stotsky, J.G. and WoldeMariam, A. (1997) Tax Effort in Sub-Saharan Africa. IMF Working Paper No. 1997107.

[19] Fenochietto, R and Pessino, C. (2010) Understanding Countries’ Tax Effort. IMF Working Paper No. WP/13/244.

[20] Martinez-Vazquez, J. and McNab, R. (2000) Tax Reform in the Tax Reform Experiment in Transitional Countries. International Centre for Public Policy, Andrew Young School of Policy Studies, Georgia State University, Atlanta.

[21] Chelliah, R.J., Baas, H.J. and Kelly, M.R. (1975) Tax Ratios and Tax Effort in Developing Countries, 1969-71. IMF Staff Papers, 22, 187-205. http://dx.doi.org/10.2307/3866592

[22] Keen, M. and Mansour, M. (2010) Revenue Mobilization in Sub-Saharan Africa: Challenges from Globalization. Development Policy Review, 28, 553-571. http://dx.doi.org/10.1111/j.1467-7679.2010.00498.x

[23] Hisali, E. (2012) Trade Policy Reform and International Trade Tax Revenue in Uganda. Economic Modelling, 29, 2144-2154. www.elsevier.com/locate/ecmod http://dx.doi.org/10.1016/j.econmod.2012.06.033

[24] Khattry, B. and Rao, J.M. (2002) Fiscal Faux Pas? An Analysis of the Revenue Implications of Trade Liberalization. World Development, 30, 1431-1444. http://dx.doi.org/10.1016/S0305-750X(02)00043-8

[25] Tanzi, V. and Blejer, M.I. (1988) Public Debt and Fiscal Policy in Developing Countries. In: Arrow, K.J. and Boskin, M.J., Eds., The Economics of Public Debt, International Economic Association, Macmillan, London.

[26] Agbeyegbe, T., Stotsky, G. and WoldeMariam, A. (2004) Trade Liberalization, Exchange Rate Changes, and Tax Revenue in Sub-Saharan Africa. IMF Working Paper No. 2004-178.

[27] Wibbels, E. and Moisés, A. (2003) Globalization, Taxation, and Burden-Shifting in Latin America. International Organization, 57, 111-136. http://dx.doi.org/10.1017/S0020818303571041

[28] Aizenman, J. and JinJarak, Y. (2009) Globalization and Developing Countries-A Shrinking Tax Base? Journal of Development Studies, 45, 653-671. http://dx.doi.org/10.1080/00220380802582338

[29] Baunsgaard, T. and Keen, M. (2009) Tax Revenue and (or?) Trade Liberalization. IMF Working Paper 2005-112. Journal of Public Economics, 94, 563-577.

[30] Tanzi, V. (1987) Quantitative Characteristics of the Tax Systems of Developing Countries. In: Newberry, D. and Stern, N.H., Eds., The Theory of Taxation for Developing Countries, Oxford University Press for the World Bank, New York, 205-241.

[31] Senhadji, A. (1998) Time-Series Estimation of Structural Import Demand Equations: A Cross-Country Analysis. IMF Staff Papers, 45, 236-268. http://dx.doi.org/10.2307/3867390

[32] Maren, M. (1997) The Road to Hell: The Ravaging Effects of Foreign Aid and International Charity. The Free Press, New York.

[33] Wacziarg, R. and Welch, K.H. (2003) Trade Liberalization and Growth: New Evidence. NBER Working Paper No. 10152.

[34] Slemrod, J. (2004) Are Corporate Tax Rates, or Countries, Converging? Journal of Public Economics, 88, 1169-1186. http://dx.doi.org/10.1016/S0047-2727(03)00061-6

[35] Dickey, D.A. and Fuller, W.A. (1981) Likelihood Ratio Statistics for Autoregressive Time Series with a Unit Root. Econometrica, 49, 1057-1072. http://dx.doi.org/10.2307/1912517

[36] Teera, J. (2003) An Appraisal of Uganda’s Tax Performance. Working Paper, University of Bath, Bath.

[37] Brautigam, D. (2000) Aid Dependence and Governance. Almqvist \& Wiksell International, Stockholm. 
Scientific Research Publishing (SCIRP) is one of the largest Open Access journal publishers. It is currently publishing more than 200 open access, online, peer-reviewed journals covering a wide range of academic disciplines. SCIRP serves the worldwide academic communities and contributes to the progress and application of science with its publication.

Other selected journals from SCIRP are listed as below. Submit your manuscript to us via either submit@scirp.org or Online Submission Portal.
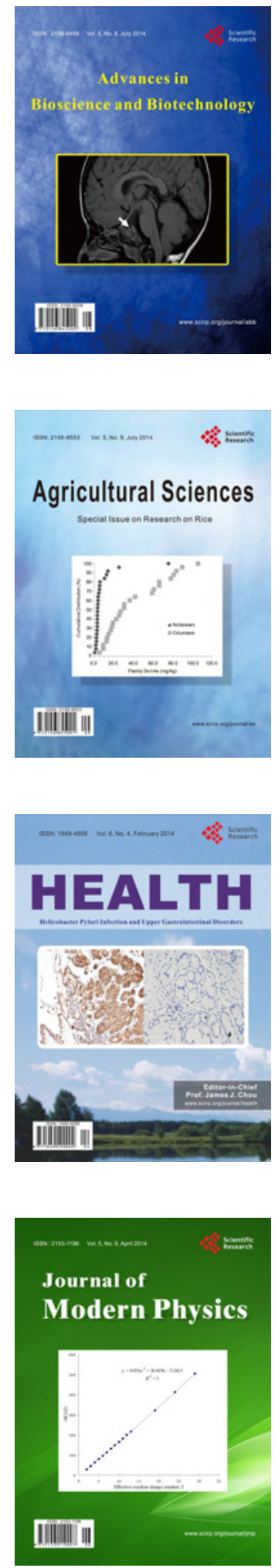
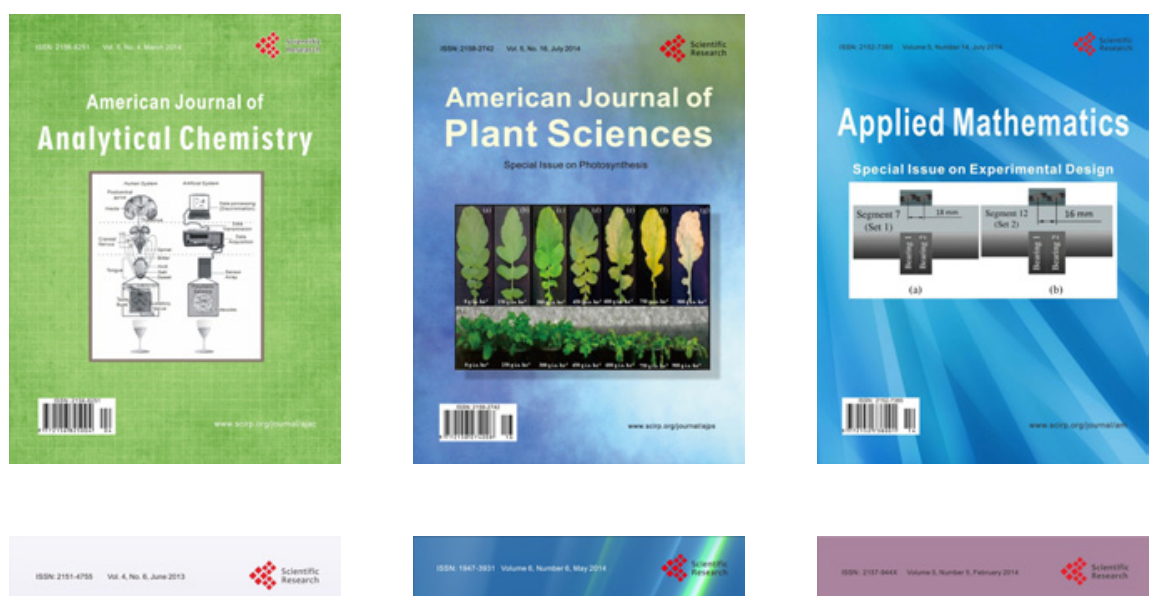

Creative Education
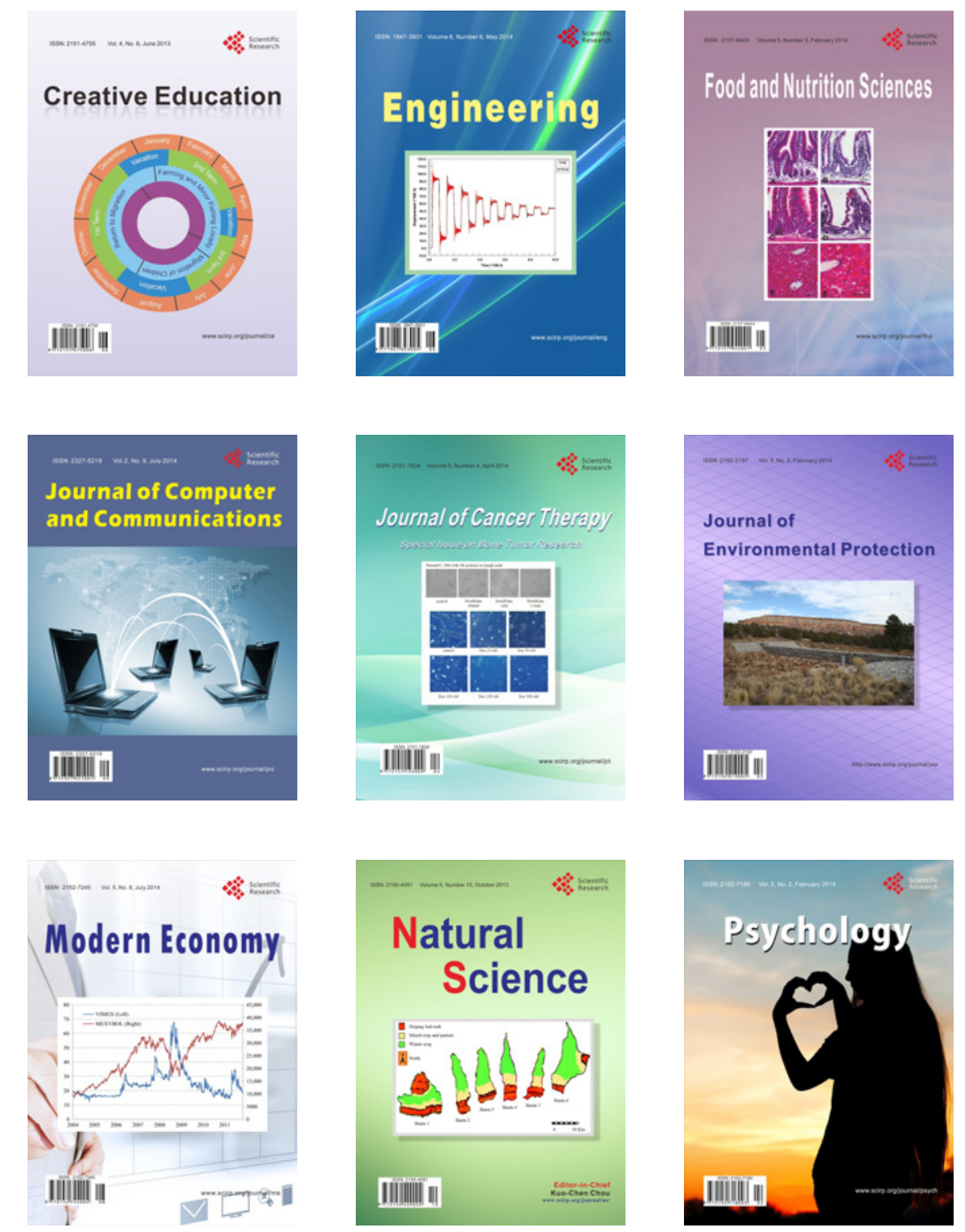